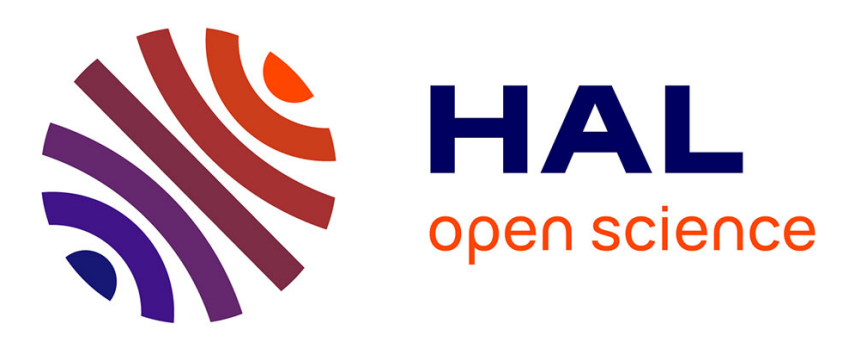

\title{
From the Popularization of Microscopy in the Victorian Age: A Lesson for Today's "Outreach"
}

\author{
John R. Dolan
}

\section{To cite this version:}

John R. Dolan. From the Popularization of Microscopy in the Victorian Age: A Lesson for Today's "Outreach". Protist, 2019, 170 (3), pp.319-327. 10.1016/j.protis.2019.05.003 . hal-02172314

\section{HAL Id: hal-02172314 https://hal.sorbonne-universite.fr/hal-02172314}

Submitted on 3 Jul 2019

HAL is a multi-disciplinary open access archive for the deposit and dissemination of scientific research documents, whether they are published or not. The documents may come from teaching and research institutions in France or abroad, or from public or private research centers.
L'archive ouverte pluridisciplinaire HAL, est destinée au dépôt et à la diffusion de documents scientifiques de niveau recherche, publiés ou non, émanant des établissements d'enseignement et de recherche français ou étrangers, des laboratoires publics ou privés. 


\title{
From the Popularization of Microscopy in the Victorian Age: A Lesson for Today's "Outreach"
}

\author{
John R. Dolan ${ }^{1}$
}

CNRS, Laboratoire d'Océanographie de Villefranche-sur-Mer, BP 28, France

\begin{abstract}
In the latter half of the Victorian Age (1837-1901) microscopy was introduced as popular past-time. Many books were published aimed at general audiences, both adult and juvenile, on microscopy. Here I consider 5 of these popular books of particular interest to protistologists as they included presentations of 'infusoria' or 'animalcules'. I focus on the scientific backgrounds of the authors, from what we know of them, and the approaches taken to engage the reader based on their texts and illustrations. The possible lesson to be drawn from this exercise concerns our oft-mandated efforts in "Outreach". The methods used by 19th century popularizes of the 'wonders of the microscopic world' can likely be used today. They appealed to the imagination, to empowerment, and gave very practical instructions on how to see the invisible. I conclude that we should likely target the very young and describe our organisms with the enthusiasm that brought us to Protistology to begin with, but which we often conceal.
\end{abstract}

1dolan@obs-vlfr.fr 


\section{Microscopists and Microscopes of the Last Half of the 19th Century}

Science in the 19th century appears to have been more social than it is today. For example, my contact with a public audience is limited to participation in the annual 'open house' day of my institute. Contact with my fellow protistologists is mainly indirect, through reading and publishing articles, and direct only through attending a large conference or two per year. In the later half of the 19th century, 'doing science' was not simply conducting research but also acting in "a set of community-based activities" (Belknap 2018). The community was often a heterogeneous group as the categories of 'amateur' and 'professional' were not clear-cut (Barton 2003). In Britain, the community activities included participation in local clubs, many later to become scientific societies; as well participation in local events termed "Conversaziones", gatherings held by a learned or art society and attended by the genteel public. These "Conversaziones", described as ubiquitous cultural events, included exhibitions of instruments, demonstrations, and lectures (Alberti 2003). For example, in the city of Plymouth, there were 3 to 5 such events per year in the years from 1851 to 1865 (Plunkett \& Sullivan 2012). One can assume then the 19th century microscopist was liable to be very fond of showing off his or her microscope and what it revealed (see Fig. 1).

A large factor in the growth of the popularity of microscopy was the fact microscopes of reasonable quality were available in the later half of the 19th century for affordable prices, at least for the relatively well-to do. For example, Pritchard in the end pages of his book 'Notes on Natural History' offered a "standard achromatic" for $£ 15$ (Pritchard 1854). In 'A few words on the choice of a microscope', Plummer (1860) noted that while models of a "very high order" furnished with "the best object glasses and all necessary apparatus" cost from $£ 20$ - $£ 40$ he also pointed out that 'student' microscopes were available for as little as $3-5 £$. Putting these prices in perspective to costs of living at that time is difficult. However, in terms of wages in the mid-1860's, in the building trades, $5 £$ was 3 weeks wages for an artisan and 2 weeks wages for an engineer (Bowley 1900). In terms of my salary as a research scientist, 2 weeks wages before taxes, etc., is about $£ 2,500$ a sum that buys a good student microscope. For another 
comparison, consider that in 1860 an upright piano could be had for $£ 20$ (anonymous 1865). Thus, as it is today, a hobbyist microscope was a substantial but not outrageous purchase, much like buying an upright piano. In fact, in the later half of the 19th century, the microscope became a common object in the Victorian domestic parlour (Lightman 2010).

FIGURE 1 HERE at Full Page Width

\section{Introducing the General Public to the Microscopic World: Popularization of Microscopy}

William Saville Kent in his Manual of the Infusoria (1880-1881) provided a chronological list of works up to 1881 pertaining to the infusoria. Perusing his list, one can see when works with 'popular' titles appeared. Clearly Saville Kent may have been unaware of, or omitted, some titles but his listing provides a handy summary. Books supposedly directed to a large public, given the title, date back to 1742 with Henry Baker's "The Microscope made Easy". However, we now know that in the 18th century microscopes were neither easily acquired nor easy to use. The books considered below were all published when microscopes had become relatively 'user friendly' and inexpensive as remarked upon in most of books. The later half of the 19th century also corresponded to the period of the rise of a mass market for books as printing technologies created the possibility of inexpensive volumes for a growing middle class market. An example is the 'inexpensive version for 1 schilling', "Common Objects of the Microscope" (Fig. 2) one of a large series of very popular "Common Objects" natural history books by Reverend R.G. Wood (Lightman 2000). While some of the authors had formal scientific training, others were very, very, talented amateurs.

FIGURE 2 HERE at half page width

The Invisible World Revealed by the Microscope; or, Thoughts on Animalcules 
The first popular title in the 19th century in Saville Kent's bibliography appears to be "Thoughts on Animalcules: a glimpse of the invisible world" by G. A. Mantell (1846). Mantell was a very renowned physician, geologist and a pioneer of paleontology. He was primarily known for his discovery of dinosaurs. Notably, Mantell does not appear to have been professionally concerned with microorganisms, as among his many publications there are but 2 short papers on fossil microorganisms. The book then seems to have been a labor of love, produced after he received a microscope as a gift from the membership of the "Clapham Athenaeum of the Advancement of Literary and Scientific Knowledge" (Swinton 1975). A long review appeared in the Lancet (Anon. 1846). Little or no technical knowledge is assumed of the reader. The introductory chapter though does assume a familiarity with Milton, Byron, and Locke. Notably, at length, it reminds us that both invisible (gnomes and fairies) and magical creatures (i.e., wizards) were until recently part and parcel of our culture. The magical reference may be seem odd but recall that the regenerative capacity of the Hydra was a source of amazement (Ratcliff 2012). His goal was clearly stated in the preface (below), in one very long sentence.

"The object of this Volume is to present a familiar exposition of the nature and habits of some of the invisible beings which people our lakes and streams ; in the hope, that by placing the most interesting phenomena in a striking point of view, and describing them in language divested as much as possible of scientific terms, the subject may be rendered attractive to the general reader, and some intelligent and inquiring minds be led to the cultivation of a branch of natural knowledge, pre-eminently calculated to impart just and comprehensive views of the grandeur and harmony of the Creation, and of the Infinite Wisdom and Beneficence of its Divine Author ; and which, in every condition and circumstance of life, will prove a never-failing source of pleasure and instruction."

The volume included 12 color plates. Mantell tells us that the illustrations were drawn by himself or his daughter, using a camera lucida, suggesting that microscopy was a family past-time. The drawings illustrated the fine structure of 
microorganisms (Fig. 3). The appendices included information on where and how to sample as well as where to acquire microscopes and their prices.

Drops of Water; their Marvelous and Beautiful Inhabitants Displayed by the Microscope

The second popular book in the chronology of Saville Kent is the 1851 book by Agnes Catlow, "Drops of water; their marvelous and beautiful inhabitants displayed by the microscope". Women at that time were not allowed to attend university, to be members of scientific societies, or even allowed to use university libraries. These facts make it remarkable that Agnes Catlow and her sister Maria were accomplished writers of popular books on natural history. Agnes Catlow authored texts on "conchology" and gardening, while her sister wrote on entomology and botany. Together they published a book of illustrations "Sketching rambles: or Nature in the Alps and Alpennines." Thus, like Mantell, Catlow did not in her other writings show any major interests or expertise in microorganisms. She states that her motivation in writing the book is simply due to having derived great pleasure from examining minute water creatures with her microscope. She targeted her book to the "beginner" and in a most mystical manner as in the introductory paragraph below. Curiously in my view, the book is often classified as juvenile literature. While no technical knowledge is assumed, the reader is often referred to Ehrenberg for details and I imagine that his publications were unlikely to be widely available. It is illustrated with very attractive color plates (see Fig. 4) but which number but 4.

"To give an idea of the wonders to be found in this new world, to which I wish to lead the reader, I shall describe one scene amongst the many to be witnessed. My readers must fancy themselves spirits, capable of living in a medium different from our atmosphere, and so pass with me through a wonderful brazen tunnel, with crystal doors at the entrance. These doors are bright, circular, and thick, of very peculiar construction, having taken much time and labour to bring to perfection. A spirit named Science opens them to all who seek her, and feel induced to enter her domains. At the end of the tunnel we find other portals, much 
smaller, and more carefully constructed, and two or three in number; when these are opened, we are in the new world spoken of. And now I see your astonishment: your minds are bewildered with the variety of new beings and forms you behold, all gliding and moving about without noise and at perfect ease."

FIGURE 4 HERE at half-page width

The Microscope, or Descriptions of Various Objects of Especial Interest and Beauty, Adapted for Microscope Observation

Mary Ward was an unusual woman and her book, first self-published in 1857, has an unusual history. Ward was raised in a well-to-do family, her interests in natural history, telescopes and microscopes was encouraged by her father who gave her at age 7 a copy of Buffon's Natural History and at age 18 a Ross microscope, the finest microscope available at the time (Harry 1984). Married at age 27 , she had 8 children in the next 14 years but nonetheless published books on microscopy, telescopes and botany. Her life story is included in the book "Daughters of Maeve: 50 Irish women who changed the world"(Sigillito 2007) as well as in "The role of women in the history of geological studies in Ireland (Higgs \& Wyse Jackson 2007). Ward's book "The Microscope" began as a series of letters to a friend which she decided to turn into a book, in the 'manner of a panorama', to present an exhibition of wonders. She had the book (Ward 1857) printed herself along with handbills to advertise it and quickly sold the 250 copies she had had printed. A London publisher then offered to publish it but changed the authorship to 'Honorable Mrs. Ward ' to give Ward some authority. The commercially published book went through several editions under various titles and is listed among scientific "best sellers" and "steady sellers" of the Victorian age (Lightman 2007, see figs 9.1, 9.2). It is written in a nearly conversational tone. It is somewhat a 'how to' guide as it includes chapters on assembling a microscope out of the box and mounting objects for examination, as well as those showing off microscope features and creatures. This combination of practicality and wonderment is evident in the figure below (Fig. 5). It shows 
that one can remove the microscope barrel from the frame and arrange it using household objects so that one can inspect fantastic organisms in a wine glass. According to Laura Forsberg, for Ward, the essential purpose of the microscope was not to reveal truth but rather beauty (Forsberg 2015).

FIGURE 5 HERE at half-page width

Half-Hours with the Microscope; Being a Popular Guide to the Use of the Microscope as a Means of Amusement and Instruction

This small 1859 book (10x $15 \mathrm{~cm})$ by Edwin Lankester is the only one considered here that does not appear in the listing of Saville Kent. Its omission is interesting as he was a very well-known figure in microscopy. He was the editor of the Quarterly Journal of Microscopy (now the Journal of Cell Science) from its inception in 1853 to his death. His passing was noted in relatively lengthy obituaries in Nature, the British Medical Journal, and Lancet all remarking on not only his many accomplishments in the fields of medicine and public health, but as well noting the popularity of his Half Hours book (anon. 1874a; anon. 1874b anon. 1874c). It was a book that sold very well, over 7000 copies of the first two editions. The edition published in the USA was very favorably reviewed in the American Naturalist (RHW 1874). The book was continuously re- issued until 1892 with the 18th edition.

Lankester's introductory text, which appears after the first plate (Fig. 5) tells the readers that they are being empowered with the microscope.

"What eyes would be to the man who is born blind, the Microscope is to the man who sees only with his naked eye. It opens a new world to him, and thousands of objects whose form and shape, and even existence, he could only imagine, can now be observed with accuracy."

He also though gave microorganisms purpose and personality, perhaps so the reader could relate to them. 
"If, now, we go to a very dirty pond indeed, into which cesspools are emptied, and dead dogs and cats are thrown, we shall find abundant employment for our Microscope in the beautiful forms of animalcules which are placed by the Creator in these positions to clear away the dirt and filth, and prevent its destroying the life of higher animals. In such waters, amongst a host of minor forms, we are almost sure to meet with the magnificent Paramecium Aureli... He moves about the water a king amongst the smaller prey, on whom he feeds without ceasing."

FIGURE 6 HERE at half-page width

Marvels of Pond-Life or, a Year's Microscopic Recreations among the Polyps, Infusoria, Rotifers, Water-Bears, and Polyzoa

This, our last book, was written by Henry Slack. He was primarily a journalist, and secondarily, a microscopist. He was though quite accomplished at both. He served as secretary first, and then latter, president of the Royal Microscopical Society, publishers of the Journal of Microscopy, the oldest journal of microscopy. He is listed as co-author of the 1875 edition of Carpenter's The Microscope and its Revelations (Carpenter \& Slack 1875), one of the standard manuals of microscopy of the era. Besides writing for a variety of periodicals, Slack edited semi-popular periodicals such as "The Intellectual Observer: Review of Natural History, Microscope Research, and Recreative Science". His obituary in Nature described him as one of the most keen journalistic champions of science (anon. 1895). The notice also mentions that for Slack "science had its duties as well as its rights". The intended audience of Marvels of Pond Life is stated to be the young microscopist and a review of the second edition in Nature (anon. 1871) describes it as a "first book to guide the young student". It is remarkable as a popular microscopy book because it takes a temporal approach to investigating microscopic life, introducing the reader to seasonal changes in microscopic flora and fauna in single locale. It is handsomely illustrated (e.g., Fig. 7). As with Lankester, the introduction tells the reader that that the microscope will reveal unimagined wonders but Slack adopted a nearly evangelical manner. 
"Our minds ache at the contemplation of astronomical immensities, and we are apt to see the boundless only in prodigious masses, countless numbers, and immeasurable spaces. The Creative Mind knows no such limitations; and the microscope shews us that, whether the field of nature's operation be what to our apprehension is great or small, there is no limit to the exhibition of marvellous skill. If the "undevout astronomer" be "mad," the un-devout microscopist must be still more so, for if the matter be judged by human sense, the skill is greater as the operation is more minute; and not the sun itself, nor the central orb round which he revolves, with all his attendant worlds, can furnish sublimer objects of contemplation, than the miraculous assemblage of forces which make up the life of the smallest creature that the microscope reveals."

FIGURE 7 HERE at half-page width

\section{A lesson from 19th Century Popular Presentations of Microorganisms?}

People of diverse backgrounds, educations, and major interests penned the popular books considered here. Perhaps not surprisingly, there are some distinct differences among them. In particular, references to "higher orders" ranged from a Christian God responsible for Divine Order (the Creator), to a spirit named Science, and the Creative Mind. Also the intended audiences, as juvenile or general, differed among the books. Despite these differences, all presented microorganisms in similar fashion. Microorganisms are shown to be intricate wonders living secret and silent existences in plain site, simply too small to be seen without a microscope. While some references were made to infer a certain utility to microorganisms (e.g. cleaning of filthy waters), microorganisms are mainly presented as objects of beauty and wonder. This somewhat clashes with our contemporary depictions that, while not excluding beauty, usually emphasize biological roles, and even potential commercial values. These latter items, roles and potential value, involve presenting non-intuitive explanations 
and scenarios and demand an intellectual engagement of the audience. In contrast, simple displays can demonstrate beauty and inspire wonder.

I believe most of us entered protistology not after learning of the vital roles played by protists or their economic possibilities, but rather after being exposed to, and then enthralled by, the microscopic world. I argue then that our "outreach" efforts should always include a large component on the beauty and intricacies of protists. Often we tend to shy away from admitting what first us brought us to protistology, preferring to trot out practical or intellectual justifications, referring to roles in ecosystems, or 'big questions to be answered' the origins of life or multicellularity, the effects of climate change and such. These considerations are real and pressing but in explaining them we should not forget to mention the wonder that brought us into our unusual field to begin with.

Wonder is far easier to inspire in a young person than an adult. This is not only because adults can be more jaded than youth but also because we ourselves are liable to be more restrained in our presentation when the audience is adult. Doing "outreach" to include young audiences, including the wonders of the microscopic worlds, could make our efforts more effective and would certainly make our efforts less of an effort.

\section{Acknowledgements}

I owe the genesis of this paper to Dave Montagnes who, after enduring my showing off John Hill's 1752 "An History of Animals", suggested I write something about my old books. Encouragement for this particular effort was provided by both Michael Melkonian and Dave Montagnes. Bernard Lightman kindly provided helpful comments and suggestions on an earlier version of this work. However, I retain full responsibility for all errors of fact and interpretation.

\section{References}

Alberti JMM (2003) Conversaziones and the experience of science in Victorian England. J Victorian Cult 8:208-230 
Anon. (1846) Reviews. Thoughts on Animalcules; or, a glimpse of the Invisible World Revealed by the Microscope. by Gideon Algernon Mantell. Lancet 48:478479

Anon. (1865) Manufactures of the United States in 1860: Compiled from the Original Returns of the Eighth Census Under the Direction of the Secretary of the Interior. Government Printing Office, Washington, 745 p

Anon. (1874a) Edwin Lankester, M.D., F.R.S. Nature 11:15-16

Anon. (1874b) Edwin Lankester, M.D., L.L.D., F.R.S. Brit Med J 2:603

Anon. (1874c) Edwin Lankester, M.D., M.R.C.P., F.R.S. Lancet 140:676-677

Baker H (1742) The Microscope Made Easy. The Microscope Made Easy: or, I. The Nature, Uses, and Magnifying Powers of the Best Kinds of Microscopes Described, Calculated and Explained for the Instruction of Such, Particularly, as Desire to Search Into the Wonders of the Minute Creation, tho' they are not Acquainted with Optics, Together with Full Directions how to Prepare, Apply, Examine, and Preserve all Sorts of Objects, and Proper Cautions to be Observed in Viewing them. II. An Account of whatSurprising Discoveries have been Already Made by the Microscope, with Useful Reflections on them: and also a Great Variety of New Experiments and Observations, Pointing out Many in Common Subjects for the Examination of the Curious. R. Dodsley, Tully's Head, Pall-Mall, $311 \mathrm{p}$

Barton R (2003) "Men of science": language, identity and professionalization in the mid-Victorian scientific community. Hist Sci 41:72-119

Belknap G (2018) Illustrating natural history: images, periodicals, and the making of nineteenth-century scientific communities. Brit J Hist Sci 51:395-422 
Bowley AL (1900) Wages in the United Kingdom in the Nineteenth Century. Cambridge: Cambridge University Press, $148 \mathrm{p}$

Catlow A (1851) Drops of Water: their Marvellous and Beautiful Inhabitants Displayed by the Microscope. Reeve and Benham, London, $194 \mathrm{p}$

Carpenter WB, Slack HJ (1875) The Microscope and its Revelations. J \& A Churchill, London, $843 \mathrm{p}$

Ehrenberg, CG (1871) Über die wachsende Kenntis des unsichtbaren Lebens als felsbildende Bacillarien in Californien. Abh Königl Preuss Akad Wiss Berl, Year 1870:1-74

Fonvielle W de (1869) Les merveilles du monde invisible. Hachette, Paris, 338 p

Forsberg L (2015) Nature's invisibilia: The Victorian microscope and the miniature fairy. Victor Stud 57:638-666

Harry OG (1984) The Hon. Mrs Ward (1827-1869) artist, naturalist, astronomer and Ireland's first lady of the microscope. Ir Nat J 21:193-200

Higgs B, Wyse Jackson P (2007) The Role of Women in the History of Geological Studies in Ireland. in Burek CV, Higgs B (eds) The Role of Women in the History of Geology. Geological Society, London, pp 137-153

Lankester E (1863) Half-hours with the Microscope; Being a Popular Guide to the Use of the Microscope as a Means of Amusement and Instructions. Robert Harwick, London, $160 \mathrm{p}$

Lightman B (2000) Marketing knowledge for the general reader: Victorian popularizers of science. Endeavour 24:100-106 
Lightman B (2007) Victorian populizers of science: designing nature for new audiences. University of Chicago Press, Chicago, pp 545

Lightman B (2010) The Microscopic World. Victorian Rev 36:46-49

Mantell GA (1846) Thoughts on Animalcules : or, A Glimpse of the Invisible World Revealed by the Microscope. Murray, London, $144 \mathrm{p}$

Plumer JJ (1864) A few words on the choice of a microscope. Quart J Microsc Socs S2-4:153-167

Plunkett J, Sullivan JA (2012) Fetes, bazars and conversaziones: science, entertainment and local civic elites. in Kember J, Plunkett J, Sullivan JA (eds) Popular Exhibitions , Science and Showmanship, 1840-1910. Pickering \& Chatto, London, pp 41-60

Pritchard A (1854) Notes on Aquatic Microscopic Subjects of Natural History, Selected from the "Microscopic Cabinet". Whittaker \& Co., London, $93 \mathrm{p}$

RWH (1874) Review: Half hours with the microscope. Am Nat 8:354-355

Ratcliff MJ (2012) The Trembley effect or the birth of marine zoology. Int J Dev Biol 56:425-436

Slack, HJ (1861) Marvels of Pond-life or, a Year's Microscopic Recreations Among the Polyps, Infusoria, Rotifers, Water Bears, and Polyzoa. Groombridge and Sons, London, $197 \mathrm{p}$

Saville Kent W (1880-1881) A Manual of the Infusoria: Including a Description of All Known Flagellate, Ciliate, and Tentaculiferous Protozoa, British and Foreign and an Account of the Organization and Affinities of the Sponges. David Brogue, London, $913 \mathrm{p}$ 
Switton WE (1975) Gideon Algernon Mantell. Br Med J 1975;1:505-507

Ward M (1857). Sketches with a Microscope. Shields, Parsonstown. 


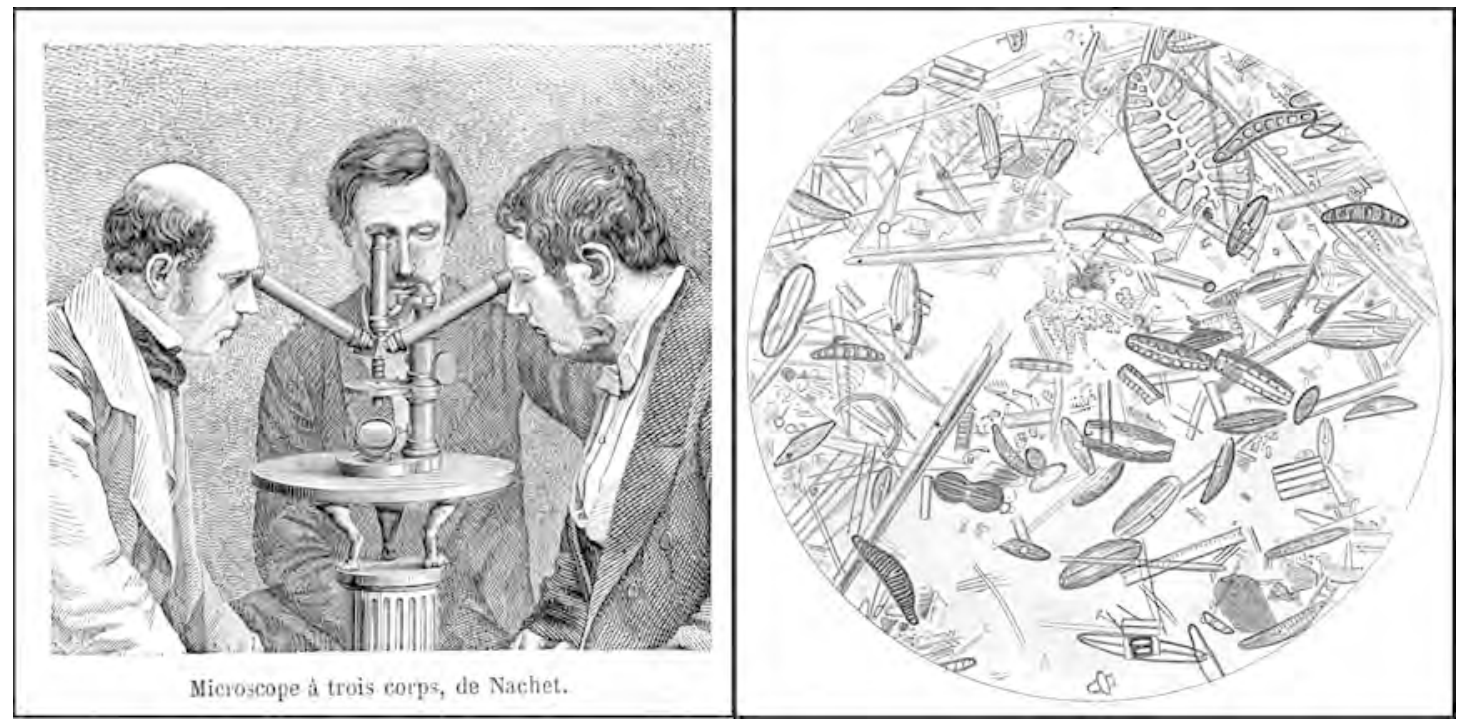

Figure 1. Microscopists and what they could see. Left panel: Gentlemen Microscopists from Fonvielle (1869); Right panel an illustration of an early photomicrograph by Gustav. T. Fritsch (specified as low magnification to provide adequate depth of field) from Ehrenberg (1870) testifying to the quality of the optics available. 


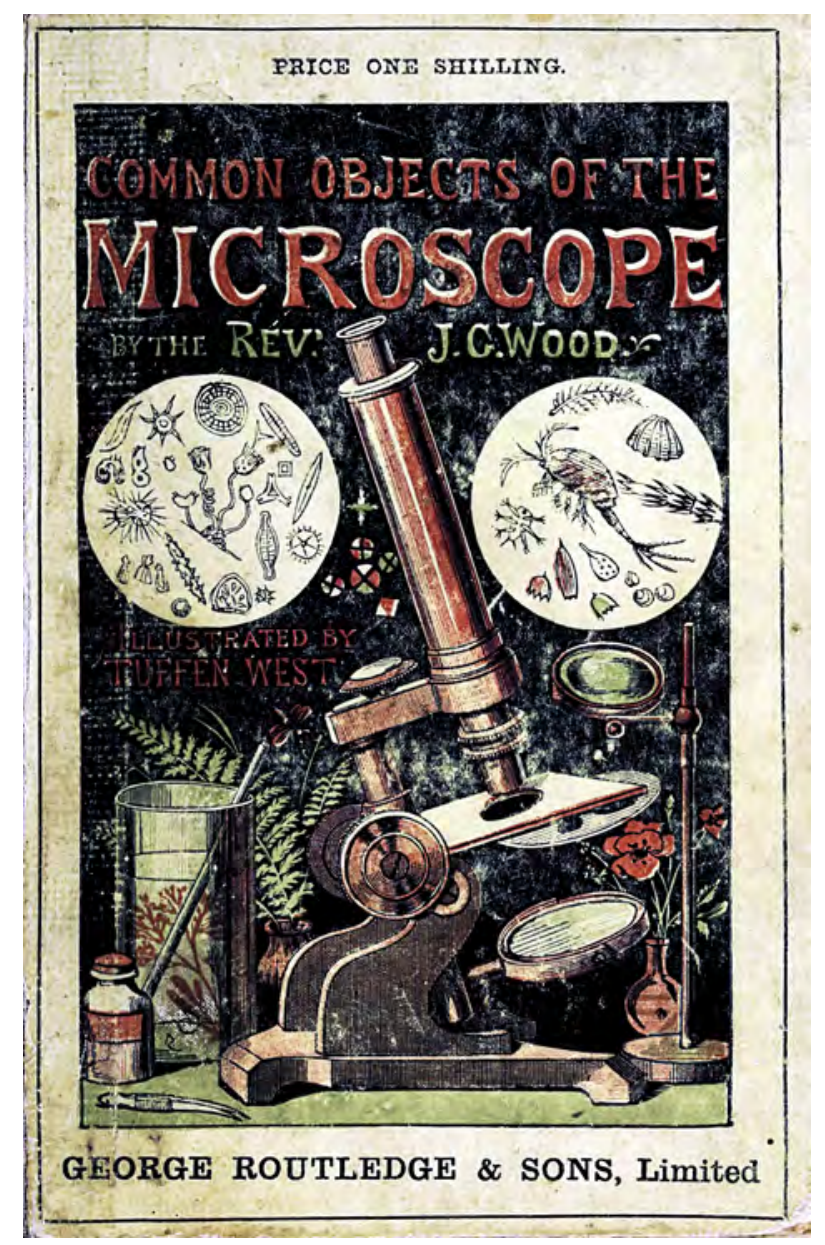

Figure 2. Cover of the 1899 edition of "Common Objects of the Microscope". The first editions were published in 1861: one edition with color plates and an "inexpensive 1 shilling" version with plates of line drawings. 


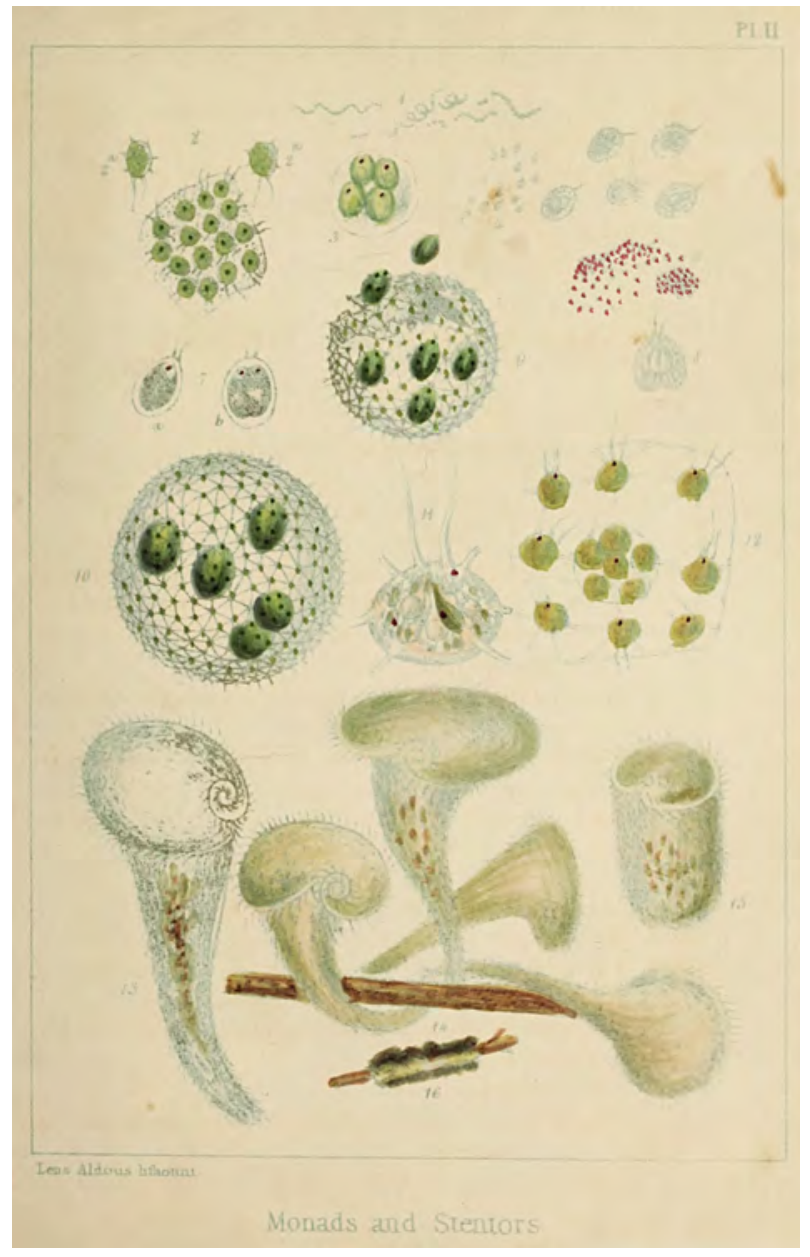

Figure 3. Plate 2 of 12 from Mantell's "The invisible world revealed by the microscope; or, Thoughts on animalcules". The illustrations were straightforward demonstrations of the fine structure of heretofore invisible creatures. 


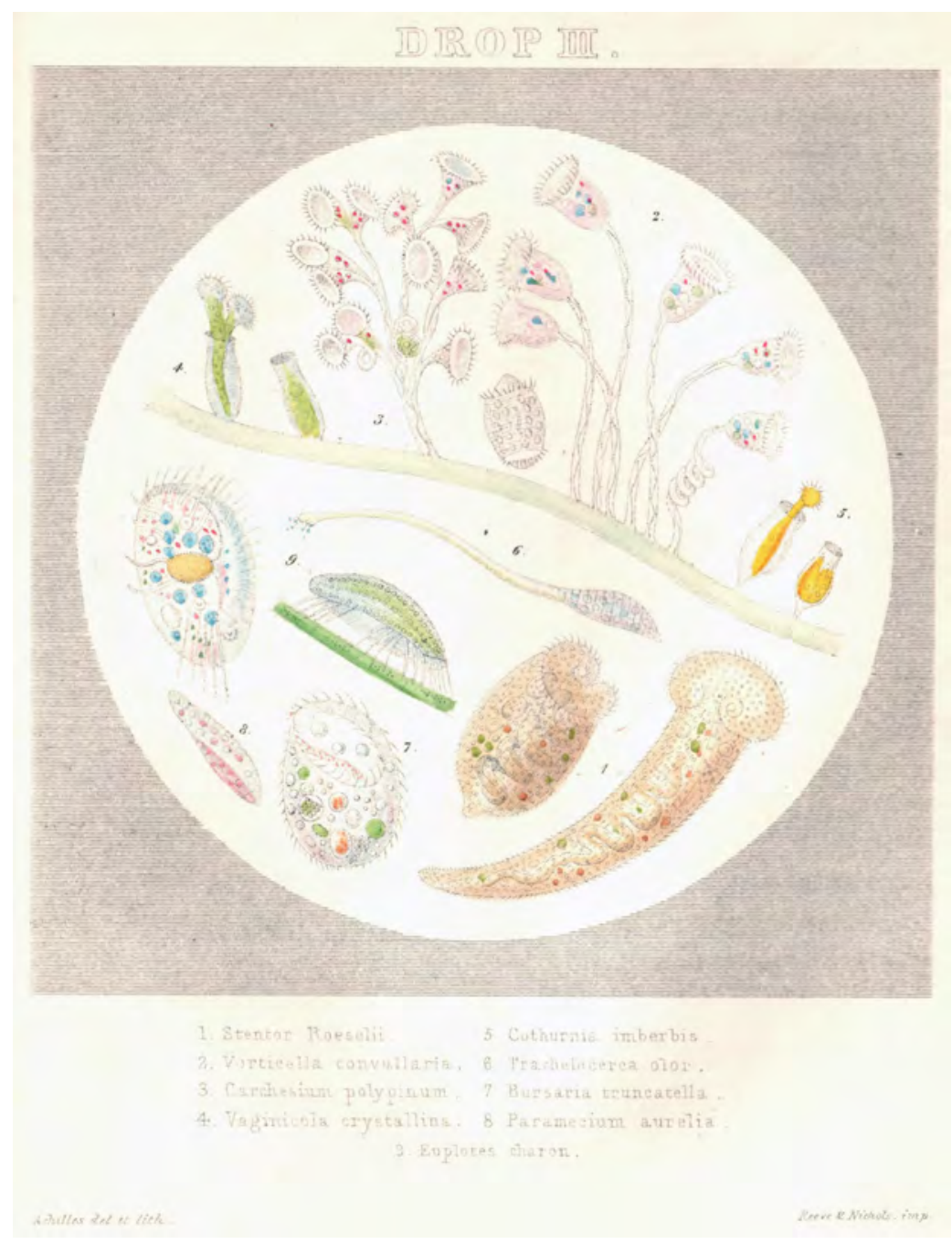

Figure 4. Drop II from Drops of Water. Catlow arranged her illustrations within a circle surrounded by black resembling a view through the ocular. The organisms shown are almost in motion with the vortecellids out-stretched ( 2 and 3 ) and the euplotid walking (9). 


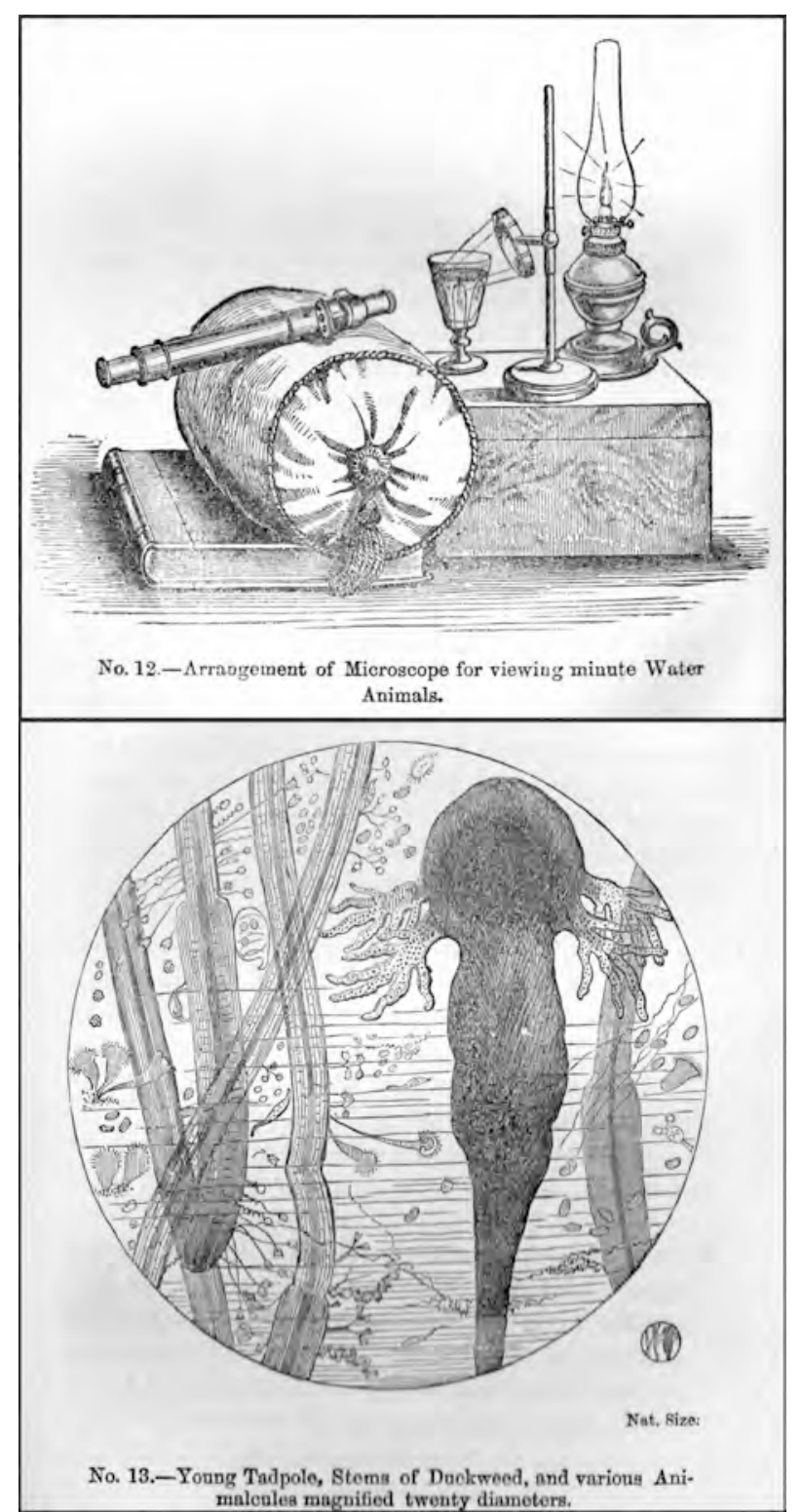

Figure 5. Figures 12 and 13 from "The Microscope, or Descriptions of Various Objects of Especial Interest and Beauty, Adapted for Microscope Observation". The figure 12 shows how to observe organisms in a wine glass of pond water. In figure 13 within the round view of the ocular is relatively large tadpole along with vorticellids and stentors associated with algal filaments. The inset showing the actual size ("Nat. Size" print size about $0.5 \mathrm{~cm}$ ) emphasizes the actual and relative sizes of the organisms revealed by the microscope. 


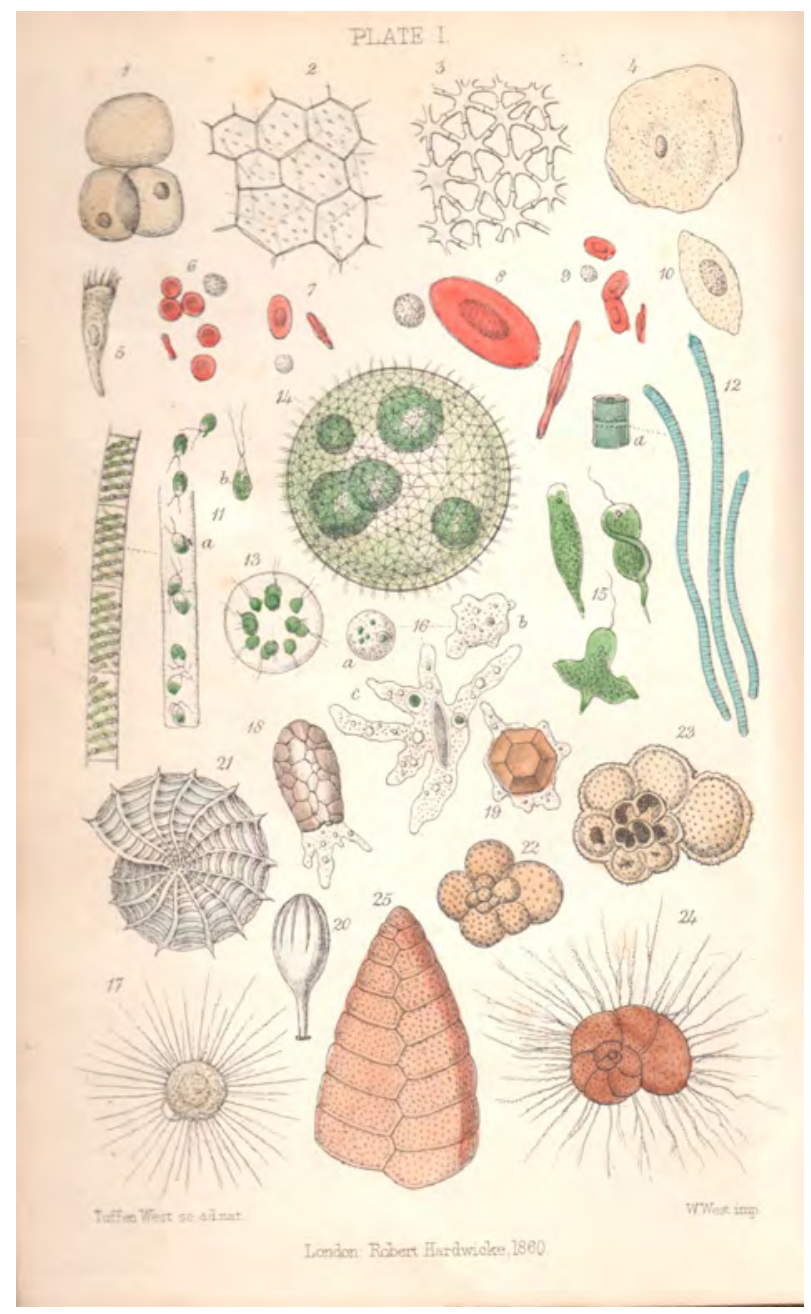

Figure 6. Plate 1 (frontispiece) of "Half-hours with the Microscope; Being a Popular Guide to the Use of the Microscope as a Means of Amusement and Instruction". A very large variety of items are shown ranging from a cell from an apple (1), a blood cell of beetle (10), Euglena (16), to diverse foraminifera (2025). Thus, facing the title page of the book, the microscope is presented as revealing both unsuspected microorganisms and unsuspected microscopic structure. 


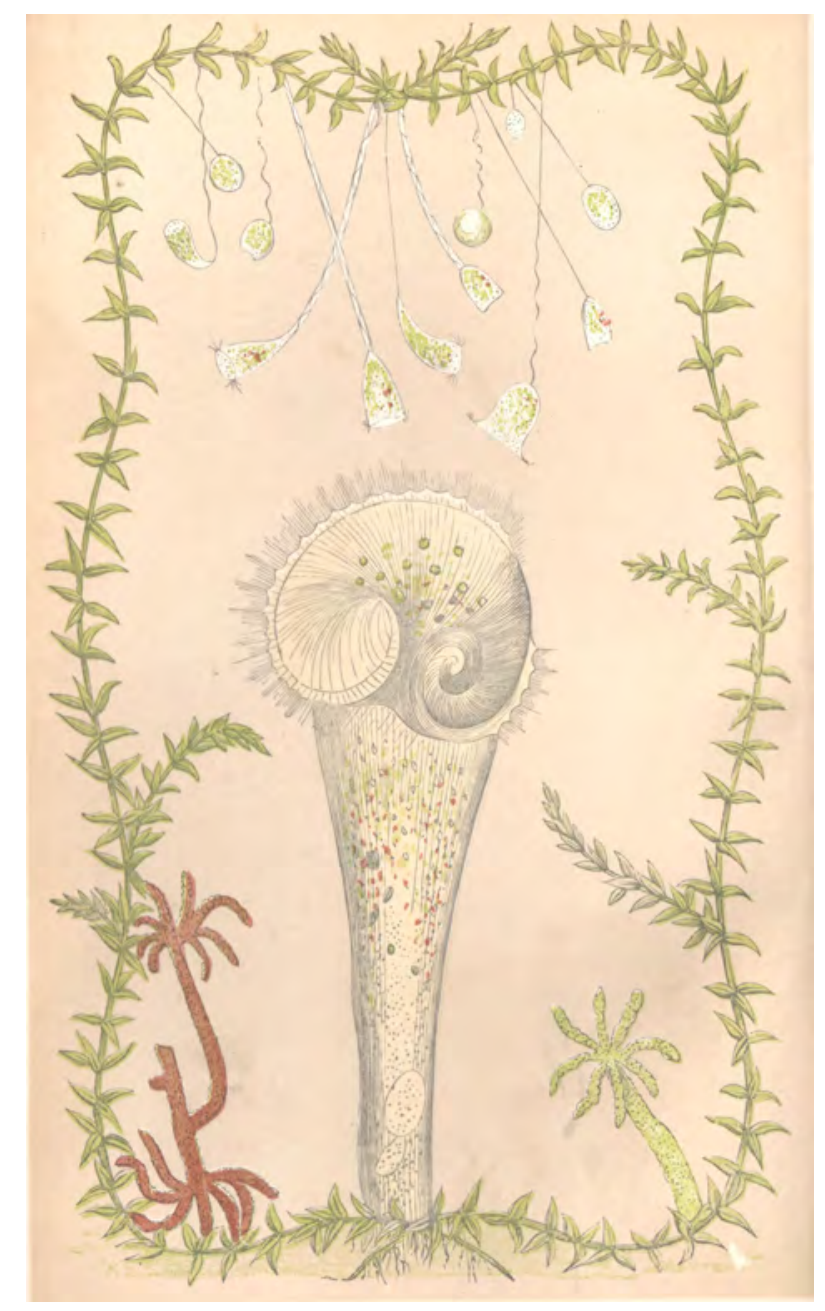

Figure 7. Plate 1 facing the title page of "Marvels of Pond-Life or, a Year's Microscopic Recreations among the Polyps, Infusoria, Rotifers, Water-Bears, and Polyzoa". The decorative arrangement is remarkable with Stentor facing dangling Vorticellids, framed by algae and Hydra. It emphasizes the "sublime" nature of the creatures revealed by the microscope. 